\title{
hsp70 AS New Cadmium Bioaccumulation Marker to prevent the risks of Mussels Consumption in Human Nutrition
}

\author{
Marina Piscopo ${ }^{1 \star}$, Rosaria Notariale ${ }^{1}$ and Jacopo Troisi ${ }^{2}$ \\ 'Dipartimento di Biologia, Universita' degli Studi di Napoli Federico II, Complesso Universitario Monte S. Angelo, 80126 Naples, Italy \\ ${ }^{2}$ Theoreo srl-spin-off dell'Università degli Studi di Salerno, 84090 Salerno, Italy
}

\section{Article Info}

\author{
*Corresponding author: \\ Marina Piscopo \\ Adjunct Professor of Molecular Biology \\ Department of Biology \\ University of Naples Federico II \\ University Complex Monte S. Angelo \\ Via Cinthia 80126, Naples \\ Italy \\ Tel: +39081679081/94 \\ Fax: +39081679233 \\ E-mail: marina.piscopo@unina.it
}

\section{Received: October 17, 2017}

Accepted: November 7, 2017

Published: November 14, 2017

Citation: Piscopo M, Notariale R, Troisi J. hsp70 AS New Cadmium Bioaccumulation Marker to prevent the risks of Mussels Consumption in Human Nutrition. Madridge J Clin Res. 2017; 2(1): 37-43.

doi: $10.18689 / \mathrm{mjcr}-1000107$

Copyright: (c) 2017 The Author(s). This work is licensed under a Creative Commons Attribution 4.0 International License, which permits unrestricted use, distribution, and reproduction in any medium, provided the original work is properly cited.

Published by Madridge Publishers

\begin{abstract}
The consumption of seafood has increased in recent years, especially in coastal regions. The consumption of mussels provides proteins, essential minerals and vitamins, and thus, some protection from certain diseases but the risks and benefits of their consumption are still hard to assess because of the metals bioaccumulated from the marine environment, with their toxicity. Mussels accumulate a wide range of metals, included cadmium, in their soft tissue. Cadmium is a heavy metal particularly hazardous for human health and is an important pollutant in estuarine and coastal environments. Thus, the determination of the concentrations of cadmium in mussels is essential because of their usage as seafood and the potential adverse effects of their consumption on human health. In order to identify a quick cadmium bioaccumulation marker usable in monitoring programs, we analyzed the metal content in Mytilus galloprovincialis gill tissues and its relationship with hsp70 expression levels after a laboratory exposure for $24 \mathrm{~h}$ to 1,$5 ; 5$ and $10 \mu \mathrm{M} \mathrm{CdCl}_{2}$ in artificial sea water. Inductively coupled plasma-mass spectrometry showed that cadmium content increased in gills tissues in an exposure dose-dependent fashion. RT-qPCR, showed that $\mathrm{Cd}$ exposure induced hsp70 increase resulting in 3,$1 ; 10$ and 12 fold at 1,$5 ; 5,10 \mu \mathrm{M}$, respectively in comparison with unexposed mussels. Finally, hsp70 expression levels correlated with the amount of bioaccumulated cadmium in gill tissue, indicating hsp70 as a potential marker, even if not univocally, of significative cadmium bioaccumulation usable in environmental monitoring programs and for seafood safety.
\end{abstract}

Keywords: cadmium; pollution; human health; Mytilus galloprovincialis; hsp70; ICP-MS; bioaccumulation; RT-qPCR; gene expression.

Abbreviations: Cd: Cadmium; Hsps: Heat shock proteins; hsp70: Heat shock proteins 70 gene; ASW: Artificial Sea Water; ICP-QMS: Inductively coupled plasma-mass spectrometry.

\section{Introduction}

Cadmium $(\mathrm{Cd})$ is a heavy metal particularly dangerous for human health and is a ubiquitous environmental toxicant [1]. About 25,000 tons of $\mathrm{Cd}$ are released into the environment mainly by weathering of rocks and through forest fires and volcanoes and in part through human activities, such as manufacturing nickel-cadmium battery, electroplating and paint pigments that utilize $\mathrm{Cd}$. An exposure to significantly higher $\mathrm{Cd}$ levels occurs also when people smoke. $\mathrm{Cd}$ for human health is particularly dangerous for kidney, testis and brain but it produces also other health effects as bone fracture, reproductive failure and infertility; damage to the immune system; psychological 
disorders; DNA damage and cancer development [2]. Cd emissions are normally transported continually between air, water and soils. Much of the $\mathrm{Cd}$ entering fresh waters from industrial sources may be rapidly adsorbed by particulate matter, and thus sediment represents a significant sink for $\mathrm{Cd}$ emitted to the aquatic environment. Partitioning of $\mathrm{Cd}$ between the adsorbed-in-sediment state and dissolved-inwater state is therefore an important factor in whether $\mathrm{Cd}$ emitted to waters is or is not available to enter the food chain and affect human health. In fact a great part of human uptake of $\mathrm{Cd}$ takes place through food. Foodstuffs that are rich in $\mathrm{Cd}$ as liver, mushrooms, shellfish, mussels, cocoa powder and dried seaweed can significantly increase $\mathrm{Cd}$ concentration in human bodies. $\mathrm{Cd}$ is transported into the lungs by tobacco smoke. Blood transports it throughout all the body where it can amplify effects by potentiating $\mathrm{Cd}$ that is already present from $\mathrm{Cd}$ rich foods.

The toxic effects induced by $\mathrm{Cd}$ include oxidative stress, cellular death and inflammation. At the moment, a therapy able to neutralize $\mathrm{Cd}$ toxicity is still lacking and the development of novel therapeutic agents is necessary. In this scenario it is therefore particularly important to find new tools usable in environmental monitoring programs for the quick identification of $\mathrm{Cd}$ polluted areas. Ecosystem health have been evaluated just by "mussel watch" programs including the NOAA National Status and Trends (NS\&T) through the chemical analyses of pollutant levels in marine bivalve tissues [3]. Mytilus galloprovincialis has proven very useful for monitoring water quality because their soft tissues incorporate exposure overtime, even when water concentrations are close to measurable levels or when pollutant levels are temporally unpredictable $[4,5]$. According to Tissue Residue approach (TRA) [6] the concentration of a contaminant at the site of toxic action is proportional to the concentration of that pollutant in the whole body and individual tissues. This approach has proven to work very well only for some toxicants as chlorophenols and nonpolar organic compounds but not for metals because the variety and efficiency of mechanisms that have evolved in various species for metal uptake, detoxification and internal sequestration [7]. So, in the last years, besides the chemical analyses, many monitoring programs take advantage also on the use of biomarkers to assess environmental health. Heat shock proteins (Hsps), acting as molecular chaperones, are constitutively expressed in cells and involved in protein folding, assembly, degradation, intracellular localization. Their over expression represents a ubiquitous molecular mechanism in response to stress.

Hsps are classified into families and amongst them, the Hsp70 family appears to be the most evolutionary conserved and distributed in animals $[8,9]$. Recently we have demonstrated that Mytilus galloprovincialis has an excellent ability to accumulate $\mathrm{Cd}$ in gills tissues, respect to other metals, since artificial sea water (ASW) containing $\mathrm{CdCl}_{2^{\prime}}$ after laboratory mussels exposure, presents a decrease of $\mathrm{Cd}$ concentration of about $96-97 \%$ [10]. Further we have already shown that a positive correlation exists between $\mathrm{Cd}$ bioaccumulation in Mytilus galloprovincialis gill tissues and $\pi$-gst expression level [10]. So in this work we have evaluated hsp70 expression and $\mathrm{Cd}$ bioaccumulation in gill tissues of Mytilus galloprovincialis exposed for $24 \mathrm{~h}$ to 1,$5 ; 5$ and $10 \mu \mathrm{M}$ $\mathrm{CdCl}_{2}$ with the aim to find another biomarker that responds in a dose-dependent manner to $\mathrm{Cd}$ bioaccumulation usable in environmental monitoring programs and for seafood safety.

$\mathrm{Cd}$ content in gills tissues was determined using inductively coupled plasma-mass spectrometry (ICP-MS) and by realtime qPCR (RT-qPCR) were evaluated expression levels of hsp70 mRNA.

\section{Methods}

\section{Ethics statement}

The research described herein was performed on the marine invertebrate Mytilus galloprovincialis (Lamarck 1819), which is not protected by any environmental agency in Italy. This study was conducted in strict accordance with European (Directive 2010/63) and Italian (Decreto Legislativo n. 116/1992) legislation on the care and use of animals for scientific purposes.

\section{Mussel samplings, treatments and gill tissues processing}

Adult mussels Mytilus galloprovincialis of mixed sex, of average size shell length $4.93 \pm 0.17 \mathrm{~cm}$, collected in winter, were provided by the Cooperative Institute for Regional Development and Implementation of mussels I.R.SV.E.M. Bacoli, in Naples. Mussels exposure to $\mathrm{CdCl}_{2}$ was performed as follows. Four plastic tanks were used and 13 mussels were placed in $5 \mathrm{~L}$ of $32 \%$ artificial sea water (ASW) in each tank. Following acclimatization for $2 \mathrm{~h}$ at $18 \pm 1^{\circ} \mathrm{C}$ in ASW, mussels were exposed for $24 \mathrm{~h}$ to three different $\mu \mathrm{M}$ amounts of $\mathrm{CdCl}_{2}$ $(1,5 ; 5$ and $10 \mu \mathrm{M})$. Water and $\mathrm{CdCl}_{2}$ were changed every $12 \mathrm{~h}$ during the treatment. A tank of the four, containing only ASW and 13 mussels (unexposed mussels: Ctrl) was used as control. For $1,5 \mu \mathrm{M} \mathrm{CdCl}_{2}$ exposure of mussels for $24,48,72$ and $96 \mathrm{~h}$, were used 2 tanks containing each 20 liters of ASW and 52 mussels. One tank was used for mussels exposure with $1,5 \mu \mathrm{M}$ $\mathrm{CdCl}_{2}$ and the other was used as control (unexposed mussels: (trl). The conditions of salinity and temperature in these tanks were the same described below for the experiments performed only for $24 \mathrm{~h}$ with the difference that the tanks were constantly aerated measuring by Dissolved Oxygen Meter YSI 58 (Yellow Spring Inc. Co., Ohio, USA) that oxygen values were $>90 \%$ of air saturation. At time $0 \mathrm{~h}$, a ration of Instant Algae Shellfish Diet 1800 (Reed Mariculture, Campbell, CA) was added to each tank, at the rate of $1 \times 10^{6}$ algae $/ \mathrm{mL}$ of seawater. Musselfeeding was repeated at the same rate at $24 \mathrm{~h}$ and then reduced to $5 \times 10^{5}, 5 \times 10^{4}, 5 \times 10^{3}$ algae/mL of water at 48 , 72 , and $96 \mathrm{~h}$, respectively, since 13 mussels were removed from each tank for daily testing.

After $\mathrm{CdCl}_{2}$ exposure, individual gills were rapidly rinsed in physiological solution, frozen in liquid nitrogen and stored at $-80{ }^{\circ} \mathrm{C}$ until RNA purification and $\mathrm{Cd}$ bioaccumulation analyses. 


\section{Total RNA extraction, cDNA synthesis and RTqPCR}

Total RNA was purified from individual gill using the Trizol reagent (Invitrogen) in agreement to the manufacturer's instructions. RNA samples were quantified and their quality was checked with the spectrophotometer NanoDropH ND1000 and by $1 \%$ agarose gel electrophoretic analysis in denaturant condition according to Rave et al. (1979) [11]. Equal amounts of RNA obtained from tissues of 5 control mussels and 5 mussels exposed to each $\mu \mathrm{M}$ concentrations of $\mathrm{CdCl}_{2}$ were used in RT-qPCR analyses. All the total RNA extracted were purified to genomic DNA with DNasi reaction according to the protocol Ambion DNA-free kit before retro transcription to avoid the amplification of contaminant genomic DNA. cDNA was synthesized using M-MLV reverse transcriptase according to the protocol of Promega Imp Prom II kit. Nine $\mu \mathrm{g}$ of RNA from each samples were used to perform CDNA syntheses using random examers $(0.5 \mu \mathrm{g} / \mu \mathrm{g}$ RNA). cDNA diluted 1:3 was applied in RT-qPCR assay, using $0.5 \mathrm{mM}$ of each forward and reverse primers in a final volume of $25 \mu \mathrm{L}$, to determine the expression of hsp70. Gene expression was quantified using the SYBR Green PCR Master Mix Kit (Applied Biosystems) and specific primers on the 7500 Real Time PCR System (Applied Biosystems).

Real-time PCR conditions were: $50{ }^{\circ} \mathrm{C}$ for $2 \mathrm{~min} ; 10 \mathrm{~min}$ at $95{ }^{\circ} \mathrm{C}$, followed by 40 cycles of $95^{\circ} \mathrm{C}$ for $15 \mathrm{~s}$ and $60{ }^{\circ} \mathrm{C}$ for 1 min and then $95^{\circ} \mathrm{C}$ for $15 \mathrm{~s}$. We performed the PCR reactions using $18 \mathrm{~S}$ rRNA as internal reference. The primers set used for 18S rRNA and hsp70 gene were designed using the open source software Primer3: (18S rRNA primers $F / R$ : GCCACACGAGATTGAGCAAT/CTCGCGCTTACTGGGAATTC; hsp70primers F/R: CGCGATGCCAAACTAGACAA/ TCACCTGACAAAATGGCTGC. Each primer pair was preliminarily subjected to PCR to ensure the presence of a single primary amplicon, as evidenced by $2 \%$ agarose gel electrophoresis (data no shown). The dissociation curves of the RT-qPCR products for all transcripts showed single peaks. We calculated the relative gene expression values with the $\Delta \Delta C T$ method according to Livak and Schmittgen (2001) [12]. In agreement to other authors, we found the expression levels of the ribosomal gene $18 \mathrm{~S}$ essentially stable [13]. All samples and the internal reference were run and amplified in triplicate. Prior to the relative quantitative analysis, a standard curve was produced by using four serial dilutions of the mixed RT products from all the dose points and the corresponding efficiencies for each primer pair were calculated according to the equation $E=10^{(-1 / \text { slope) }}$ (correlation coefficients were $>0.98$. Hence, we measured the change in expression of hsp70 transcripts relative to the reference 18S rRNA in gill tissues samples from mussels exposed to $\mathrm{Cd}$ in comparison to control mussels (unexposed mussels).

\section{Elemental analysis by inductively coupled plasma-mass spectrometry (ICP-QMS)}

Elemental analysis was performed according to Piscopo et al., (2016) [10]. Briefly, 250 $\pm 100 \mathrm{mg}$ of sample was digested with DigiBlock sample preparation system (LabTech, MA, USA) using Teflon vessel. Digestions were performed using $10 \mathrm{~mL}$ of nitric acid (Optima-grade) and $3 \mathrm{ml}$ of $30 \% \mathrm{H}_{2} \mathrm{O}_{2}$ (Optimagrade). Samples were dissolved in $10 \mathrm{~mL}$ of $18.2 \mathrm{M} \Omega \mathrm{cm}$ at 25 ${ }^{\circ} \mathrm{C} \mathrm{H}_{2} \mathrm{O}$ with $2 \%$ nitric acid (both optima-grade). Metal quantification was carried out with a quadrupole inductively coupled plasma-mass spectrometry, ICP-QMS (820MS, Bruker). Standard stock solution of $20.00 \mathrm{mg} / \mathrm{L}$ was used for calibration. Calibration curves were obtained using 9 standard solutions. Reagent blanks containing ultra-pure water were additionally analyzed in order to control reagent purity and laboratory equipment. Metals quantification were performed using 10 $\mu \mathrm{g} / \mathrm{L}$ internal standard solution $\left({ }^{6} \mathrm{Li},{ }^{45} \mathrm{Sc},{ }^{72} \mathrm{Ge},{ }^{89} \mathrm{Y},{ }^{103} \mathrm{Rh},{ }^{159} \mathrm{~Tb}\right.$, ${ }^{165} \mathrm{Ho},{ }^{209} \mathrm{Bi}$ ). Blank samples (water with $2 \%$ nitric acid) and at least 2 standard samples were analyzed every 10 samples. In order to control the accuracy of analysis every 10 samples, certified reference of NIST bovine liver was also analyzed.

\section{Statistical analysis}

Statistical analysis was performed using Statistica software (StatSoft, Oklahoma, USA) and Minitab (Minitab Inc, Pennsylvania, USA). After multiple attempts to normalize the data (e.g., natural log, square root, inverse transformations), non-parametric statistical tests were employed (normality was tested via ShapiroWilk test). The comparison between groups was made with the Rank Sum Test, according to Mann-Whitney or by means of analysis of variance on rank preformed single way (according to Kruskal-Wallis), also using the post hoc test of Dunn. The alpha value was set to 0.05 . Correlations between data were analyzed with a Spearman's rank correlation $(\alpha=0.05)$.

\section{Results \& Discussion}

In recent years, many factors, but most of all, anthropogenic activities have increased contamination of aquatic environment and since a large fraction of contaminants can be transferred through the food chain, this makes them a potential threat to entire ecosystems and even human beings [14, 15]. As metal pollutants contamination increases, particularly in less developed countries, it is important to determine the level of pollution in the marine environment, especially in regions where aquaculture is foreseen and where the local population consumes large amounts of mussels. For its persistent nature, long distance transport and toxicity to aquatic organisms, aquatic pollution by cadmium is a real hazard to the environment and human health [16]. Mytilus galloprovincialis represents an important sentinel species for monitoring changes in coastal ecosystems thank to its ability to accumulate various contaminants, included metals $[17,18]$ and in fact has been extensively used in various mussel watch programs. Although eating mussels provides proteins, essential minerals and vitamins, protecting from certain diseases, the risks and benefits of their consumption are still difficult to evaluate for the metals bioaccumulated from the marine environment, with their toxicity considering also that the tolerable $\mathrm{Cd}$ weekly intake (TWI) is $2.5 \mu \mathrm{g} / \mathrm{kg}$ body weight set by the European Food safety Authority (EFSA) in 2009. Transcriptomic, proteomic, and metabolomic biomarkers are likely to be among the first responses to contaminant stress. So, over the past 10 years, "omic" approaches have allowed the identification of novel 
biomarkers $[19,20]$ which are of great potential value to marine monitoring programs. Induction of Hsps is considered as an important protective, ecophysiologically adaptive, and genetically conserved response to environmental stress in all organisms. Hsps are responsive not only to transient sublethal heat shock but also in the resistance toward hypoxia, ischemia, inflammation, and exposure to such cellular toxins as heavy metals, endotoxins, and reactive oxygen species [21]. Among the various $h s p$ isoforms, hsp70 is often the prominent protein to be expressed following environmental assaults [22] and its response is not only dependent on the type of pollutant, species, duration, concentration, but also organ-specific [23]. The gills are the most important uptake site for waterborne cadmium [24]. They are sensitive to several changes of water components and represent a good indicator of water quality since gill filaments and lamellae provide an extremely large surface area for direct and continuous contact with contaminants in water. For fishes the concentration of metals in gills indicates heavy metal past exposure in water where the marine organism lived [25]. People are often exposed to $\mathrm{Cd}$, so in this work, to analyze the possibility that hsp70 could to be a $\mathrm{Cd}$ bioaccumulation marker usable in monitoring programs and for seafood safety, we have evaluated $\mathrm{Cd}$ bioaccumulation and hsp70 expression levels in gill tissues of Mytilus galloprovincialis specimens exposed for $24 \mathrm{~h}$ to 1,$5 ; 5$ and $10 \mu \mathrm{M} \mathrm{CdCl}_{2}$. In this study we have chosen three $\mathrm{CdCl}_{2}$ concentrations. Two of these values $(1.5$ and $5 \mu \mathrm{M})$ fall within the limits of survival for estuarine/marine invertebrate aquatic life while $10 \mu \mathrm{M}$ fall in the chronic toxicity (Aquatic Life Ambient Water Quality Criteria - Cadmium 2016 - EPA)

The analyses performed by ICP-MS show that the exposure for $24 \mathrm{~h}$ to individual $\mu \mathrm{M}$ amounts of $\mathrm{CdCl}_{2}$ results in bioaccumulation of $\mathrm{Cd}$ in Mytilus galloprovincialis gill tissues (Figure 1). Cd bioaccumulation shows a linear grow up with the exposure dose.

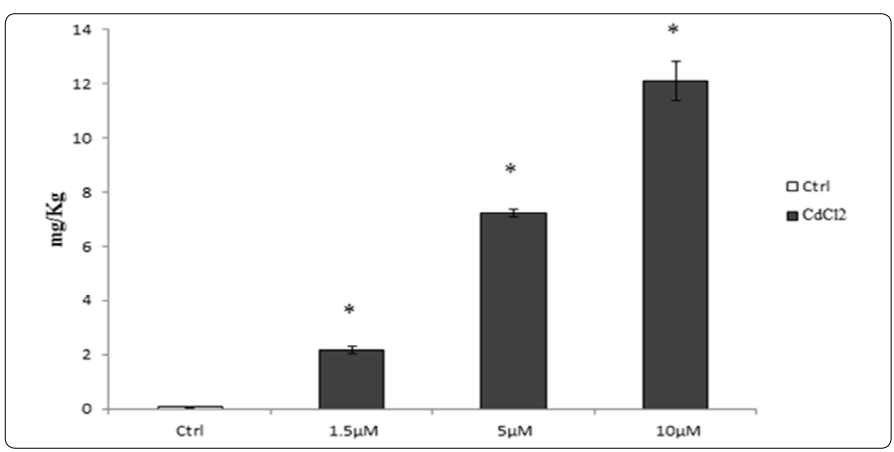

Figure 1. Cd bioaccumulation in gill after mussels exposure

Cd bioaccumulation in gill tissue of Mytilus galloprovincialis specimens exposed for $24 \mathrm{~h}$ to 1,$5 ; 5$ and $10 \mu \mathrm{M} \mathrm{CdCl}$. Analyses were performed by ICP-QMS. Ctrl means unexposed mussels used as control. The values are expressed on the wet weight basis. $\mathrm{N}=5$; Asterisk indicates a statistically significant difference $(p<0.05)$ compared to Ctrl. Cd bioaccumulation in Mytilus galloprovincialis gills shows a linear increase with exposure dose.

In order to evaluate gill tissues hsp70 expression changes induced by exposure of mussels for $24 \mathrm{~h}$ to increasing $\mu \mathrm{M}$ amounts of $\mathrm{CdCl}_{2}$ we performed RT-qPCR analyses and Figure 2 reports the results obtained and shows that the exposure to $\mathrm{CdCl}_{2}$ produced 3,$1 ; 10$ and 12 fold increase of gill hsp70 expression at 1,5; 5, $10 \mu \mathrm{M}$ respectively respect to Ctrl.

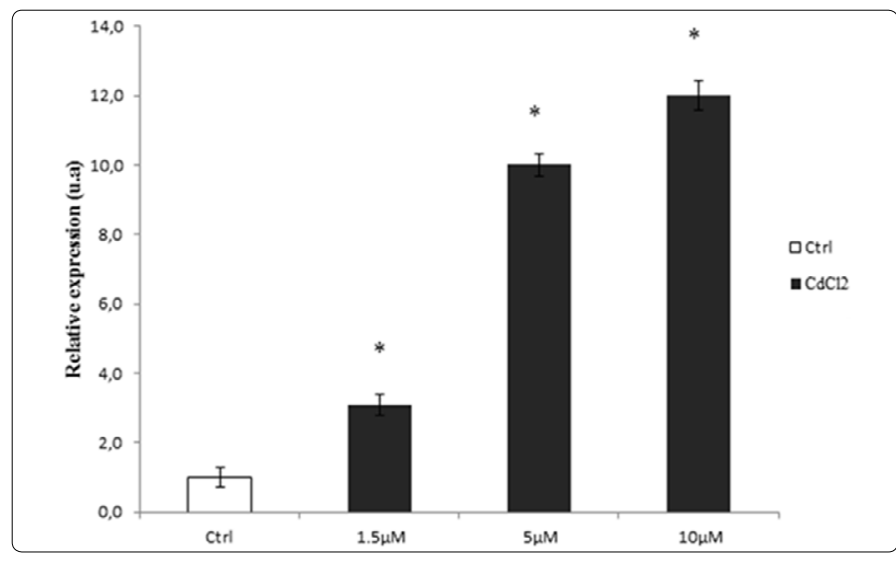

Figure 2. hsp70 expression in gill after mussels exposure

hsp70 expression level of gill tissue of Mytilus galloprovincialis specimens exposed for $24 \mathrm{~h}$ to 1,$5 ; 5$ and 10 $\mu \mathrm{M} \mathrm{CdCl}$. Analyses were performed by RTqPCR. The relative expression of hsp70, indicated as arbitrary units (u.a.), means the change in expression of the transcripts of hsp70 gene in comparison to that of the reference housekeeping $18 \mathrm{~S}$ rRNA gene in gill samples from mussels exposed to $\mathrm{CdCl}_{2}$ with respect to unexposed mussels used as control: (Ctrl); $\mathrm{N}=5$; asterisk indicates a statistically significant difference $(p>0.05)$ compared to $\mathrm{Ctrl}$. hsp70 expression in Mytilus galloprovincialis gills shows a linear increase with exposure dose.

hsp 70 up-regulation that we found, following mussels exposure to $\mathrm{CdCl}_{2}$, is in line with the results reported by many other authors both in mussels $[26,27]$ and in other organisms as in the snail Physa acuta [28] and in the planarian Dugesia japonica [29] after cadmium exposure also if, almost in all cases, hsp 70 up regulation has been evaluated and found only at higher doses respect to those used in our study.

Finally we checked whether there was a correlation between $\mathrm{Cd}$ bioaccumulation and hsp70 expression in Mytilus galloprovincialis gills tissues and found that, $\mathrm{Cd}$ bioaccumulation shows an excellent correlation with the increase of hsp70 expression with an R2 value of 0.9937 (Figure 3).

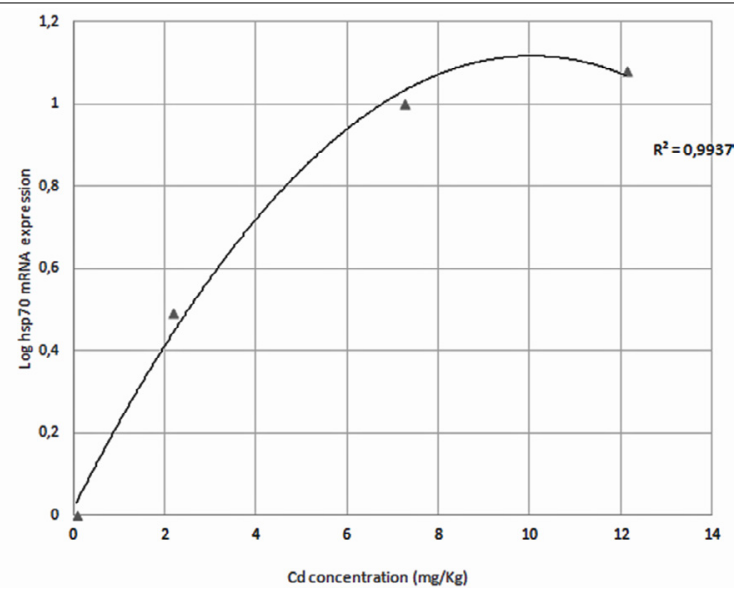

Figure 3. Correlation between Cd biaccumulated and hsp70 expression in gill tissue 
Correlation between $\mathrm{Cd}$ concentrations and hsp70 mRNA expression in gill tissue of Mytilus galloprovincialis (log transformed). The line represents the model that better describe the data variation. $R$ represents the coefficient of determination. The amount of $\mathrm{Cd}$ bioaccumulated in Mytilus galloprovincialis gills correlates with hsp70 gene expression.

Then, in this investigation, changes in hsp70 mRNA expression in gill of Mytilus galloprovincialis exposed to $\mathrm{CdCl}_{2}$ revealed that this gene can be used as a promising biomarker for $\mathrm{Cd}$ contamination in this species also at sub-lethal cadmium doses. In fact the expression of this gene not only increases in a dose dependent manner but there is an excellent correlation between $\mathrm{Cd}$ bioaccumulation and hsp70 expression. Since cadmium is known to produce toxic effects also already at very low concentrations it's very important the prompt identification of sub-lethal cadmium doses especially to reduce $C d$ health risk to heavy mussel consumers. Of course it's very important the evaluation of hsp70 mRNA in response to longer exposure to lower concentration of $\mathrm{Cd}$, that could better mimic a real condition of water contamination. Since the average $\mathrm{Cd}$ content in the world's oceans has variously been reported as low as $<5 \mathrm{ng} / \mathrm{L}[30]$ and $5-20 \mathrm{ng} / \mathrm{L}[31,32]$

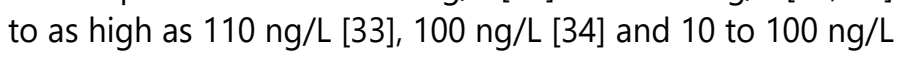
[35]. Further, higher levels of $C d$ have been reported around some coastal areas [35] and have been quantified also differences of $\mathrm{Cd}$ concentration with the ocean depth, likely due to patterns of nutrient concentrations $[30,31]$ but the majority of variations are quoted for $\mathrm{Cd}$ contents of rainwater, fresh waters, and surface waters in urban and industrialised areas. Taking into account all this data, levels from $10 \mathrm{ng} / \mathrm{L}$ to $4000 \mathrm{ng} / \mathrm{L}$ have been quoted in literature depending on specific location and whether or not total $\mathrm{Cd}$ or dissolved $\mathrm{Cd}$ is measured $[30,31,35]$. As already stated, $\mathrm{Cd}$ may be present in the environment both from natural and anthropogenic sources. In open seawater $\mathrm{Cd}$ varies between 0.02 and 0.1 $\mu \mathrm{g} / \mathrm{L}$, but in environments impacted by human activities, concentrations can be several micrograms per liter or greater [36] because the emission ratio of anthropogenic to natural $\mathrm{Cd}$ can be as high as 7:1 [36]. In saline waters cadmium is mainly complexed by chloride. The $\mathrm{Cd}$ cation is the most bioavailable chemical form but several factors affect $\mathrm{Cd}$ bioavailability in water included salinity, $\mathrm{pH}$, dissolved organic carbon, and water hardness (calcium and magnesium). In sediments, humic material and acid volatile sulfides ( $\mathrm{FeS}$ ) will be important controls on $\mathrm{Cd}$ bioavailability. Other ions that can affect $\mathrm{Cd}$ uptake or toxicity include manganese, zinc, and selenium [37]. Then, considering all this, we thought that $\mathrm{CdCl}_{2}$ concentration that could better mimic a real condition of sea water contamination, between the three considered in this paper might be $1.5 \mu \mathrm{M}$. So we exposed mussels for 24,48 , 72 and $96 \mathrm{~h}$ at this $\mathrm{CdCl}_{2}$ concentration and evaluated the level of gills hsp70 expression every day. In fig. 4 is reported the result obtained by qPCR analyses which shows that the exposure of mussels at this $\mathrm{CdCl}_{2}$ concentration produces a gill hsp70 expression level almost constant in a range of time of 4 days.

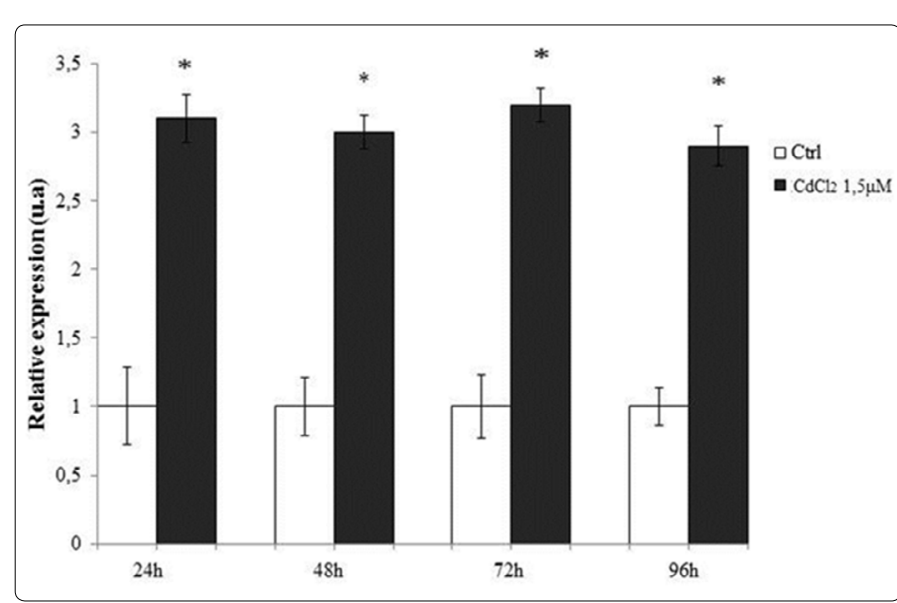

Figure 4. hsp70 expression in gill after mussels exposure at 1,5 $\mu \mathrm{M}$ $\mathrm{CdCl}_{2}$ for $24,48,72$ and $96 \mathrm{~h}$

hsp70 expression level of gill tissue of Mytilus galloprovincialis specimens exposed for $24,48,72$ and $96 \mathrm{~h}$ to $1,5 \mu \mathrm{M} \mathrm{CdCl}$. Analyses were performed by RTqPCR. For this experiment were used 2 tanks containing each 20 liters of ASW and 52 mussels (one used as control and the other for mussels exposure to $1,5 \mu \mathrm{M} \mathrm{CdCl}_{2}$ ). For daily testing 13 mussels were removed from each tank.

The relative expression of hsp70, indicated as arbitrary units (u.a.), means the change in expression of the transcripts of hsp70 gene in comparison to that of the reference housekeeping 18S rRNA gene in gill samples from mussels exposed to $\mathrm{CdCl}_{2}$ with respect to unexposed mussels used as control: (Ctrl); $\mathrm{N}=5$; asterisk indicates a statistically significant difference $(p>0.05)$ compared to Ctrl. hsp70 expression in Mytilus galloprovincialis gills shows a costant value in the range 24- $96 \mathrm{~h}$.

Of course, it will be very interesting to continue these studies and further investigate by carrying out mussel $\mathrm{CdCl}_{2}$ exposure for much longer times and even at lower $\mathrm{CdCl}_{2}$ concentrations so that this could be the subject of future investigations.

In conclusion, our results could provide a further diagnostic tool for $\mathrm{Cd}$ pollution evaluation using Mytilus galloprovincialis gill tissue that could be useful in ecotoxicological studies, risk assessment and bioremediation and could be a promising tissue for further biomarkers identification. Finally, these results will contribute to a better insight of $\mathrm{Cd}$ toxicity in the aquatic environment.

\section{Conclusions}

The present study demonstrated the inducibility of Mytilus galloprovincialis gill hsp70 by cadmium, a relevant environmental contaminant, also at non-lethal levels. Further a positive correlation exists between cadmium concentration in gill of Mytilus galloprovincialis and hsp 70 expression suggesting that hsp70 in Mytilus galloprovincialis could be a suitable biomarker, even if not univocally, of significative cadmium bioaccumulation in Mytilus galloprovincialis gill tissue usable in monitoring programs and for seafood safety. 


\section{Acknowledgments}

We want thank the Cooperative Institute for Regional Development and Implementation of mussels I.R.SV.E.M. Bacoli, in Naples for kindly providing the mussels used for this study.

\section{Funding}

This work was performed with departmental funds headed to Marina Piscopo (Dept. Biology; University of Napoli Federico II; Italy).

\section{Author Contributions}

Marina Piscopo designed the experiments; Jacopo Troisi performed the ICP-MS experiments. Marina Piscopo and Rosaria Notariale performed all the other experiments. Marina Piscopo and Jacopo Troisi analyzed the data; Marina Piscopo wrote the manuscript.

\section{References}

1. Das $S$, Raj R, Mangwani N, Dash H, Chakraborty J. Heavy metals and hydrocarbons: adverse effects and mechanism of toxicity. In Elsevier (ed). Microbial biodegradation and bioremediation. USA. 2014.

2. Sharma B, Singh S, Siddiqi NJ. Biomedical implications of heavy metals induced imbalances in redox systems. Biomed Res Int. 2014. doi: $10.1155 / 2014 / 640754$

3. Cantillo AY. Comparison of results of mussel watch programs of the United States and France with worldwide mussel watch studies. Mar Pollut Bull. 1998; 36(9): 712-717. doi: 10.1016/S0025-326X(98)00049-6

4. Viarengo A, Canesi L. Mussels as biological indicators of pollution. Biol Cultiv Mussels Aquac. 1991; 94(2-3): 225-243. doi: 10.1016/0044-8486(91)90120-V

5. Poynton HC, Varshavsky JR, Chang $B$, et al. Daphnia magna ecotoxicogenomics provides mechanistic insights into metal toxicity. Environ Sci Technol. 2007; 41(3): 1044-1050. doi: 10.1021/es0615573

6. Meador JP, McCarty LS, Escher BI, Adams WJ. $10^{\text {th }}$ anniversary critical review: the tissue-residue approach for toxicity assessment: concepts, issues, application, and recommendations. J Environ Monit. 2008; 10(12):1486-1498. doi:10.1039/b814041n

7. Luoma SN, Rainbow PS. Why is metal bioaccumulation so variable? Biodynamics as a unifying concept. Environ Sci Technol. 2005; 39: 19211931. doi: $10.1021 /$ es048947e

8. De-Maio A. Heat shock proteins: facts, thoughts, and dreams. Shock. 1999; 11: 1-12.

9. Feder ME, Hofmann GE. Heat-shock proteins, molecular chaperones and the stress response: evolutionary and ecological physiology. Ann Rev Physiol. 1999; 61: 243-282. doi:10.1146/annurev.physiol.61.1.243

10. Piscopo $M$, Ricciardiello $M$, Palumbo $G$, Troisi J. Selectivity of metal bioaccumulation and its relationship with glutathione $\mathrm{S}$-transferase levels in gonadal and gill tissues of Mytilus galloprovincialis exposed to $\mathrm{Ni}$ (II), $\mathrm{Cu}$ (II) and Cd (II). Rendiconti Lincei Scienze Fisiche e Naturali. 2016; 27: 1-12. doi: 10.1007/s12210-016-0564-0

11. Rave $\mathrm{N}$, Crkvenjakov $\mathrm{R}$, Boedtker $\mathrm{H}$. Identification of procollagen mRNAs transferred to diazobenzyloxymethyl paper from formaldehyde agarose gels. Nucleic Acids Res. 1979; 6: 3559-3567. doi:10.1093/nar/6.11.3559

12. Livak KJ, Schmittgen TD. Analysis of relative gene expression data using real-time quantitative PCR and the 2- $-\Delta \Delta T_{T}$ method. Methods. 2001; 25(4): 402-408. doi: 10.1006/meth.2001.1262

13. Dondero F, Piacentini L, Banni M, Rebelo M, Burlando B. Quantitative PCR analysis of two molluscan metallothionein genes unveils differential expression and regulation. Gene. 2005; 345(2): 259-270. doi: 10.1016/j. gene.2004.11.031
14. Wan $\mathrm{Q}$, Whang I, Lee J. Molecular cloning and characterization of three sigma glutathione $\mathrm{S}$-transferases from disk abalone (Haliotis discus discus). Comp Biochem Physiol B Biochem Mol Biol. 2008; 151(3): 257-267. doi: 10.1016/j.cbpb.2008.07.012

15. Basile A, Loppi $S$, Piscopo $M$, et al. The biological response chain to pollution: a case study from the "Italian Triangle of Death" assessed with the liverwort Lunularia cruciata. Environ Sci Pollut Res Int. 2017. doi: 10.1007/s11356-017-9304-y

16. Ling $X P$, Zhu JY, Huang $L$, Huang HQ. Proteomic changes in response to acute cadmium toxicity in gill tissue of Paralichthys olivaceus. Environ Toxicol Pharmacol. 2009; 27(2): 212-8. doi: 10.1016/j.etap.2008.10.004

17. Hoarau P, Garello G, Gnassia-Barelli M, Romeo M, Girard JP. Effect of 4-40 $\mathrm{DDE}$, methoxychlor and imidazole on glutathione $\mathrm{S}$-transferase in the clam Ruditapes decussatus. Aquat Toxicol. 2004; 68(1): 87-94. doi: 10.1016/j. aquatox.2004.03.001

18. Vassalli QA, Caccavale F, Avagnano S, et al. New Insights into ProtamineLike Component Organization in Mytilus galloprovincialis' Sperm Chromatin. DNA Cell Biol. 2015; 34(3): 162-9. doi: 10.1089/dna.2014.2631

19. Poynton $C$, Robinson WE, Blalock BJ, Hannigan RE. Correlation of transcriptomic responses and metal bioaccumulation in Mytilus edulis L. reveals early indicators of stress. Aquat Toxicol. 2014; 155: 129-141. doi: 10.1016/j.aquatox.2014.06.015

20. Veldhoen $\mathrm{N}$, Ikonomou MG, Helbing CC. Molecular profiling of marine fauna: integration of omics with environmental assessment of the world's oceans. Ecotoxicol Environ Saf. 2012; 76: 23-38. doi: 10.1016/j. ecoenv.2011.10.005

21. Tissières A, Mitchell HK, Tracy UM. Protein synthesis in salivary glands of Drosophila melanogaster: relation to chromosome puffs. J Mol Biol. 1974; 84(3): 389-98. doi: 10.1016/0022-2836(74)90447-1

22. Koehler HR, Bartussek C, Eckwert H, et al. The hepatic stress protein (hsp70) response to interacting abiotic parameters in fish exposed to various levels of pollution. Journal of Aquatic Ecosystem Stress Recover. 2001; 8: 261-279. doi: 10.1023/A:1012935931161

23. Safari R, Shabani A, Ramezanpour S, Imanpour M, Rezvani S. Alternations of heat shock proteins ( $h s p 70$ ) gene expression in liver and gill of Persian sturgeon (Acipenser persicus Borodin, 1987) exposed to cadmium chloride. Iranian Journal of Fisheries Sciences 2014; 13(4): 979-997.

24. Reynders H, Campenhout KV, Bervoet L, Coen WMD, Blust R. Dynamics of cadmium accumulation and effects in common carp (Cyprinus carpio) during simultaneous exposure to water and food (Tubifex tubifex). Environmental Toxicology and Chemistry 2006; 25(6): 1558-1567. doi:10.1897/05-239R.1

25. Chavan VR, Muley DV. Effect of heavy metals on liver and gill of fish Cirrhinus mrigala. Int J Curr Microbiol App Sci. 2014; 3(5): 277-288.

26. You $L$, Ning $X$, Liu F, et al. The response profiles of HSPA12A and TCTP from Mytilus galloprovincialis to pathogen and cadmium challenge. Fish Shellfish Immunol 2013; 35(2): 343-50. doi: 10.1016/j.fsi.2013.04.021

27. de Boissel PGJ, Fournier $M$, Rodriguez-Lecompte JC, McKenna P, Kibenge $F$, et al. Functional and molecular responses of the blue mussel Mytilus edulis' hemocytes exposed to cadmium - An in vitro model and transcriptomic approach. Fish Shellfish Immunol. 2017; 67: 575-585. doi 10.1016/j.fsi.2017.06.001

28. Martínez-Paz P, Morales M, Sánchez-Argüello P, Morcillo G, MartínezGuitarte JL. Cadmium in vivo exposure alters stress response and endocrinerelated genes in the freshwater snail Physa acuta. New biomarker genes in a new model organism. Environ Pollut. 2017; 220: 1488-1497. doi: 10.1016/j. envpol.2016.10.012

29. Zhang $X, M o Y$, Zhou $L$, et al. Induction of hsp70, hsp90, and catalase activity in planarian Dugesia japonica exposed to cadmium. Toxicol Ind Health. 2016; 32(8): 1373-1380. doi: 10.1177/0748233714561488

30. WHO Environmental Health Criteria 134 - Cadmium, International Programme on Chemical Safety (IPCS). Monograph. 1992.

31. Organisation for Economic Co-operation and Development (OECD). Risk Reduction Monograph No. 5: Cadmium OECD Environment. 1994. 
32. Jensen A, Bro-Rasmussen F. Environmental Contamination in Europe. Reviews of Environmental Contamination and Toxicology. 1995; 125: 101 181. doi: 10.1007/978-1-4612-2890-5_3

33. CRC. Handbook of Chemistry and Physics 77th Edition. CRC Press, Inc., Boca Raton, Florida. 1996.

34. Cook ME, Morrow H. Anthropogenic Sources of Cadmium in Canada. National Workshop on Cadmium Transport into Plants, Canadian Network of Toxicology Centres. 1995; 20-21.

35. Elinder CG. Cadmium: Uses. Occurrence, and Intake. Cadmium and Health: A Toxicological and Epidemiological Appraisal. 1985
36. USEPA (US Environmental Protection Agency). 2001 update of ambient water quality criterion for cadmium. US Environmental Protection Agency, Office of Water Science and Technolog.2001

37. Zaosheng W, Changzhou Y, Hainan K, Deyi W. Mechanisms of cadmium toxicity to various trophic saltwater organisms environmental science. Engineering and technology series. 2010. 